Original Article

\title{
Effects of Gundelia tournefortii L. on biochemical parameters, antioxidant activities and DNA damage in a rat model of experimental obesity
}

\author{
Efeitos de Gundelia tournefortii L. em parâmetros bioquímicos, atividades antioxidantes \\ e danos ao DNA em um modelo de obesidade experimental de rato
}

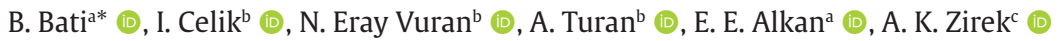 \\ ${ }^{a}$ Van Yüzüncü Yıl University, Faculty of Education, Department of Mathematics and Science Education, Van, Turkey \\ bVan Yüzüncü Yıl University, Science Faculty, Department of Molecular Biology and Genetic, Van, Turkey \\ cHakkari University, Institute of Sciences, Medical Services and Techniques, Hakkari, Turkey
}

\begin{abstract}
The present study was designed to investigate the effects of Gundelia tournefortii L. plant extract on different tissues in terms of DNA damage, biochemical and antioxidant parameter values in rats with high-calorie diets. With this aim, Wistar albino male rats were divided into 4 groups containing 6 rats each and the study was completed over 12 weeks duration. At the end of the implementation process over the 12 weeks, rats were sacrificed and blood and tissue samples were obtained. Analyses were performed on blood and tissue samples. According to results for DNA damage (8-OHdG), in brain tissue the OG2 group was significantly reduced compared to the NC group. For MDA results in liver tissue, OG1 and OG2 groups were determined to increase by a significant degree compared to the control group, while the OG2 group was also increased significantly compared to the obese group. In terms of the other parameters, comparison between the groups linked to consumption of a high calorie diet (HCD) and administration of Gundelia tournefortii L. in terms of antioxidant activities and serum samples obtained statistically significant results. Gundelia tournefortii L. plant extracts had effects that may be counted as positive on antioxidant parameter activity and were especially identified to improve DNA damage and MDA levels in brain tissues. Additionally, consumption of Gundelia tournefortii L. plant extract in the diet may have antiobesity effects; thus, it should be evaluated for use as an effective weight-loss method and as a new therapeutic agent targeting obesity.
\end{abstract}

Keywords: antioxidant activities, DNA damage, Gundelia tournefortii L., high-calorie diet, obesity, reactive oxygen species.

\begin{abstract}
Resumo
O presente estudo foi desenhado para investigar os efeitos do extrato da planta Gundelia tournefortii L. em diferentes tecidos em termos de danos ao DNA, valores de parâmetros bioquímicos e antioxidantes em ratos com dietas hipercalóricas. Com esse objetivo, ratos Wistar albinos machos foram divididos em 4 grupos contendo 6 ratos cada e o estudo foi concluído ao longo de 12 semanas de duração. No final desse processo de implementação, os ratos foram sacrificados e amostras de sangue e tecido foram obtidas. As análises foram realizadas em amostras de sangue e tecido. De acordo com os resultados para danos ao DNA (8-OHdG), no tecido cerebral o grupo OG2 foi significativamente reduzido em comparação com o grupo NC. Para os resultados de MDA no tecido hepático, os grupos OG1 e OG2 aumentaram significativamente em comparação ao grupo controle, enquanto o grupo OG2 também aumentou significativamente em comparação ao grupo obeso. Quanto aos demais parâmetros, a comparação entre os grupos ligados ao consumo de dieta hipercalórica (DC) e à administração de Gundelia tournefortii $\mathrm{L}$. em termos de atividades antioxidantes e amostras de soro obteve resultados estatisticamente significativos. Os extratos de plantas de Gundelia tournefortii L. tiveram efeitos que podem ser considerados positivos na atividade dos parâmetros antioxidantes e foram especialmente identificados para melhorar os danos ao DNA e os níveis de MDA nos tecidos cerebrais. Além disso, o consumo de extrato vegetal de Gundelia tournefortii L. na dieta pode ter efeitos antiobesidade; portanto, deve ser avaliado para uso como um método eficaz de perda de peso e como um novo agente terapêutico voltado para a obesidade.
\end{abstract}

Palavras-chave: atividades antioxidantes, dano ao DNA, Gundelia tournefortii L., dieta hipercalórica, obesidade, espécies reativas de oxigênio.

*e-mail: bediabati@yyu.edu.tr

Received: April 17, 2021 - Accepted: May 19, 2021

This is an Open Access article distributed under the terms of the Creative Commons Attribution License, which permits unrestricted use, distribution, and reproduction in any medium, provided the original work is properly cited. 


\section{Introduction}

In recent years, obesity has been encountered as a very complex disease with severe social and psychological aspects, generally affecting all age groups and threatening both developed and developing countries (WHO, 2020). Obesity is progressing and increasing worldwide related to changes in the nutritional habits of individuals; in other words, consumption of hypercaloric nutrients (Macedo et al., 2012; Meryem et al., 2016). When the etiology of obesity is examined, this disease occurs as a result of the interaction of many factors including genetic, environmental, neurologic, physiological, biochemical, sociocultural and psychological factors (Mercanligil, 2012; THSK, 2013).

Oxidative stress is disruption of the balance between prooxidants and antioxidants in biological systems; in other words, it is known to form as a result of disruption in favor of prooxidants (Berk et al., 2008; Cakmak and Gulcin, 2019; Gulcin, 2020). As a result, reactive oxygen species (ROS) damage cellular components and cellular functions. The biological targets with most damage are cellular macromolecules like DNA, proteins, carbohydrates and lipids (Gutteridge, 1994; Zadák et al., 2009; Wildburger et al., 2009). These oxidants in the organism are destroyed by the cytoplasmic, mitochondrial and extracellular forms of the antioxidant enzyme system superoxide dismutase (SOD), glutathione peroxidase (GPX), glutathione reductase (GR) and catalase (CAT) and by antioxidants like reduced glutathione (GSH) (Valko et al., 2007; Turan and Celik, 2016).

Lipid peroxidation is a marker of cellular oxidative stress, while malondialdehyde (MDA) is evaluated as a marker of damage to peroxidative cell membranes generally induced by physical or chemical oxidative stress. Additionally, high MDA level is associated with a variety of diseases (Erdurmus et al., 2011; Mumcu et al., 2016).

Reactive oxygen species (ROS), including 8-hydroxy 2-deoxygaunosine (8-OHdG), cause breakage or base changes in DNA. As a result, generally $8-O H d G$ is the most commonly used marker for oxidative DNA damage among biomarker materials (Yuki and Tsubota, 2013; Mumcu et al., 2016).

From past to present, humanity has researched the therapeutic properties of plants and used plants with this aim (Islam et al., 2020). One of the plants believed to have therapeutic properties is Gundelia tournefortii $\mathrm{L}$. This plant, in addition to many benefits, has hypoglycemic and hypolipidemic properties reducing fat and cholesterol content in blood (Asadi-Sama et al., 2013; Karaaslan et al., 2014; Qnais et al., 2016) and additionally is stated to have hepatoprotective, antioxidant, antibacterial, antiparasitic, anti-inflammatory, etc. properties (Coruh et al., 2007; Polat et al., 2012; Karaaslan et al., 2014).

This study was completed with the aim of investigating the effect of Gundelia tournefortii L. lyophilized plant extract on antioxidant and oxidative stress parameter values in a variety of tissues in rats with obesity model induced by consumption of high-calorie feed.

\section{Material and Methods}

\subsection{Reagents}

In the present study, butylated hydroxytoluene (BHT), thiobarbituric acid (TBA), potassium dihydrogen phosphate $\left(\mathrm{KH}_{2} \mathrm{PO}_{4}\right)$, trichloroacetic acid (TCA), reduced glutathione (GSH), metphosphoric acid, 5,5'-dithiobis-(2-nitrobenzoic acid) (DTNB), sodium chloride $(\mathrm{NaCl})$, trihydroxymethyl aminomethane (Tris), 1-chloro-2,4-dinitrobenzene (CDNB), oxidized glutathione (GSSG), ethylenediaminetetraacetic acid (EDTA), $\beta$-Nicotinamide adenine dinucleotide phosphate (NADPH) and sodium dihydrogen citrate anhydrous $\left(\mathrm{C}_{6} \mathrm{H}_{7} \mathrm{NaO}_{7}\right)$ were of technical grade and were supplied by Sigma Chemical Co. (St. Louis, MO, USA). Kits for the antioxidant enzyme analyses were purchased from Randox Laboratories Ltd. For DNA damage, SunRed / Rat 8-Hydroxy-desoxyguanosine (8-OHdG) ELISA Kit was used.

\subsection{Experimental animals}

Live material for the research comprised male Wistar albino rats obtained from Van Yuzuncu Yil University Experimental Animals Unit. Rats aged nearly 2 months, were housed at room temperature of $25 \pm 1^{\circ} \mathrm{C}$ with 12 hours light/ dark cycles until the end of the experiment with feeding ad libitum. The study was permitted by Van Yuzuncu Yil University Experimental Animals Ethics Committee dated 30.06.2016 and numbered "06".

\subsection{Animal groups and treatment protocol}

The study lasted 12 weeks and comprised 4 groups of 6 rats each including a control group.

- Normal Control (NC) group: 12 weeks normal rat feed

- High Calorie Diet (OC) group: 12 weeks high-calorie rat feed

- High Calorie Diet + Gundelia tournefortii L. (OG1) group: 12 weeks high-calorie rat feed + Gundelia tournefortii L. plant extract by oral gavage for the last 4 weeks (200 $\mathrm{mg} / \mathrm{kg}$ )

- High Calorie Diet + Gundelia tournefortii L. (OG2) group: 12 weeks high-calorie rat feed + Gundelia tournefortii L. plant extract by oral gavage for the last 4 weeks ( 400 $\mathrm{mg} / \mathrm{kg}$ )

All feeds (D12450B and D12451) used in the study were obtained from Research Diet. During the study the weekly weight gain of subjects was monitored and animals in the OC, OG1 and OG2 groups were evaluated for obesity. In the $8^{\text {th }}$ week of the study, body mass index (BMI) calculations were performed for subjects and they were found to be obese (Altunkaynak et al., 2008). At the end of the $8^{\text {th }}$ week of the study, the OG1 and OG2 groups were administered plant extract by oral gavage route in addition to high calorie diet. The plant extract doses administered in the study (200 and $400 \mathrm{mg} / \mathrm{kg}$ ) were suitable according to the acute toxicity test in the Organization for Economic Corporation and Development (OECD) 425 guidelines (Bati et al., 2019). 
At the end of the study rats were sacrificed and blood and tissue samples were taken. Liver, lung, kidney, brain, testis and adipose tissue samples were obtained and stored at $-80{ }^{\circ} \mathrm{C}$ until analyses.

\subsection{Plant material and extraction}

The plant material used in the present study of Gundelia tournefortii L. was collected from around Van province in the month of May. The lyophilized distilled water extract of the plant was prepared by modifying the method of Dalar and Konczak (Dalar and Konczak, 2013). The collected plant samples were divided into pieces and weighed to $100 \mathrm{~g}$. The $100 \mathrm{~g}$ plants were disintegrated in a blender with $500 \mathrm{~mL}$ distilled water. The obtained extract was homogenized in a stirrer for 2 hours at $+4{ }^{\circ} \mathrm{C}$. The homogenized mixture was centrifuged for 20 minutes at $7000 \mathrm{rpm}$. Later the supernatant was separated from the solvents with the aid of an evaporator at $+37{ }^{\circ} \mathrm{C}$. The concentrated extract was dissolved in distilled water, cooled in a freezer and then left in a lyophilizer device in $-51^{\circ} \mathrm{C}$ and 50 millitorr pressure conditions for one hour. The obtained lyophilized distilled water fraction was stored at $-20{ }^{\circ} \mathrm{C}$ until analysis procedures began.

\subsection{Preparation of tissue supernatant}

Tissues were prepared for antioxidant enzyme, reduced glutathione level and malondialdehyde tests with the following tissue extraction procedure.

For extraction, a buffer containing $0.32 \mathrm{~mol} / \mathrm{L}$ sucrose, $1 \mathrm{mmol} / \mathrm{L}$ EDTA and $10 \mathrm{~nm} / \mathrm{L}$ tris $\mathrm{HCl}$ (pH 7.4) was prepared. After tissues were thoroughly crushed with a glass rod, they were homogenized in an ultrasonic homogenator for 3-5 minutes. The homogenate was centrifuged for 30 minutes at $9500 \mathrm{rpm}$ and $+4{ }^{\circ} \mathrm{C}$ in a cooled centrifuge device (BHG Hermle). Clear supernatants obtained from liver, lung, kidney, brain and testis tissue were prepared for analyses (Turan and Celik, 2016).

The adipose tissue, left on ice, had $2 \mathrm{~mL}$ cold homogenization buffer $(500 \mu \mathrm{L} / \mathrm{L}$ triton x 100, $50 \mathrm{mM}$ Tris $-\mathrm{HCl} \mathrm{pH}$ : 7.4) placed on it. The homogenized tissue was centrifuged for $10 \mathrm{~min}$ at $3000 \mathrm{rpm}$ and $+4{ }^{\circ} \mathrm{C}$. The uppermost fat layer was removed and the supernatant below was obtained. Then $0.8 \mathrm{~mL}$ of supernatant had $400 \mu \mathrm{L}$ ethanol chloroform (ethanol:chloroform ratio $2: 3)$ mixture added. The mixture was vortexed at $4{ }^{\circ} \mathrm{C}$ and $9500 \mathrm{~g}$ for $30 \mathrm{~min}$. The supernatants obtained were prepared for analysis (Kahraman et al., 2018).

\subsection{Serum biomarker assays}

Serum biochemical parameters, AST, LDH, ALT, CRE, UREA, TG, GLU, and TC, were measured by an auto analyzer (COBAS 8000/ROCHE/Germany/Serial No 1296-08) using the kits.

\subsection{Biochemical analysis}

Malondialdehyde (MDA) content, reduced glutathione (GSH) level, superoxide dismutase (SOD), catalase (CAT), glutathione s-transferase (GST), glutathione reductase (GR), and glutathione peroxidase (GPx) enzyme activities were examined in tissues (Turan and Celik, 2016). Tissue DNA damage (8-OHdG) measurement used a Sun Red brand ELISA kit (SunRed Chemical Company cat. No. DZE 201110032).

\subsection{Statistical analysis}

Statistical analysis of the data obtained from the study groups was performed using Kruskal Wallis test and $\mathrm{R}$ package program ( $R$ Development Core Team, 2020). In addition, the significance levels in statistical tests were taken as $\mathrm{p}<0.05$.

\section{Results and Discussion}

The results obtained in the study are given in Figures 1, 2 and 3 and Table 1.

Figure 1 gives the weekly weight measurement values of the rats during the study. Accordingly, the weights of rats in the NC and OC groups generally linearly increased until the last week of the experiment, with this increase observed to be much more rapid in the OC group. In the OG1 and OG2 groups, the weight increase continued until the week when plant extracts began to be administered, with weight increase observed to stop from the $9^{\text {th }}$ week especially. The reason for this situation may be the phenolic compounds included in the plant extracts used. High fat diet is frequently used for weight gain in animals and to induce experimental obesity (Kim et al., 2000; You et al., 2014; Sayin et al., 2016). Many studies have shown the body weight of rats with high-calorie diet is increased compared to rats fed with normal diet (Niu et al., 2015; Sayin et al., 2016; Punhagui et al., 2018).

According to the biochemical parameters in Figure 2, in terms of AST level the OG1 and OG2 groups reduced as compared to the NC group and in terms of ALT level the OC group reduced compared to the NC group and the OG1 group increased compared to the OC group and all these were statistically significant $(p<0.05)$. Additionally, in terms of LDH level, the OG1 group reduced compared to the OC group, and the OG2 group reduced by statistically significant levels compared to both the NC and OC groups $(\mathrm{p}<0.05)$. In terms of TG level, the OG2 group had a statistically significant reduction as compared to the NC group $(\mathrm{p}<0.05)$. In conclusion, fluctuations were observed in the values for biochemical parameters (Figure 2). The emergence of this situation is thought to be due to feeding with a high-calorie diet because this diet style is known to trigger free radical formation. Related to this, a study by Hernández-Guerrero et al. (2018) stated that obesity triggered free radical formation in the environment increasing oxidative stress. Some studies on this topic have observed fluctuations in biochemical parameter values (Arao et al., 2004; Li et al., 2016; Amri et al., 2017). In obese subjects, the increase in serum creatinine levels is known to cause other risk factors like elevation of kidney function tests and hypertension, diabetes and dyslipidemia (Matsushita et al., 2009; Halima et al., 2018). A study by Halima et al. (2018) stated that rats fed with HFD had higher creatinine levels compared to the control group; however, administration of apple cider vinegar (ACV) 


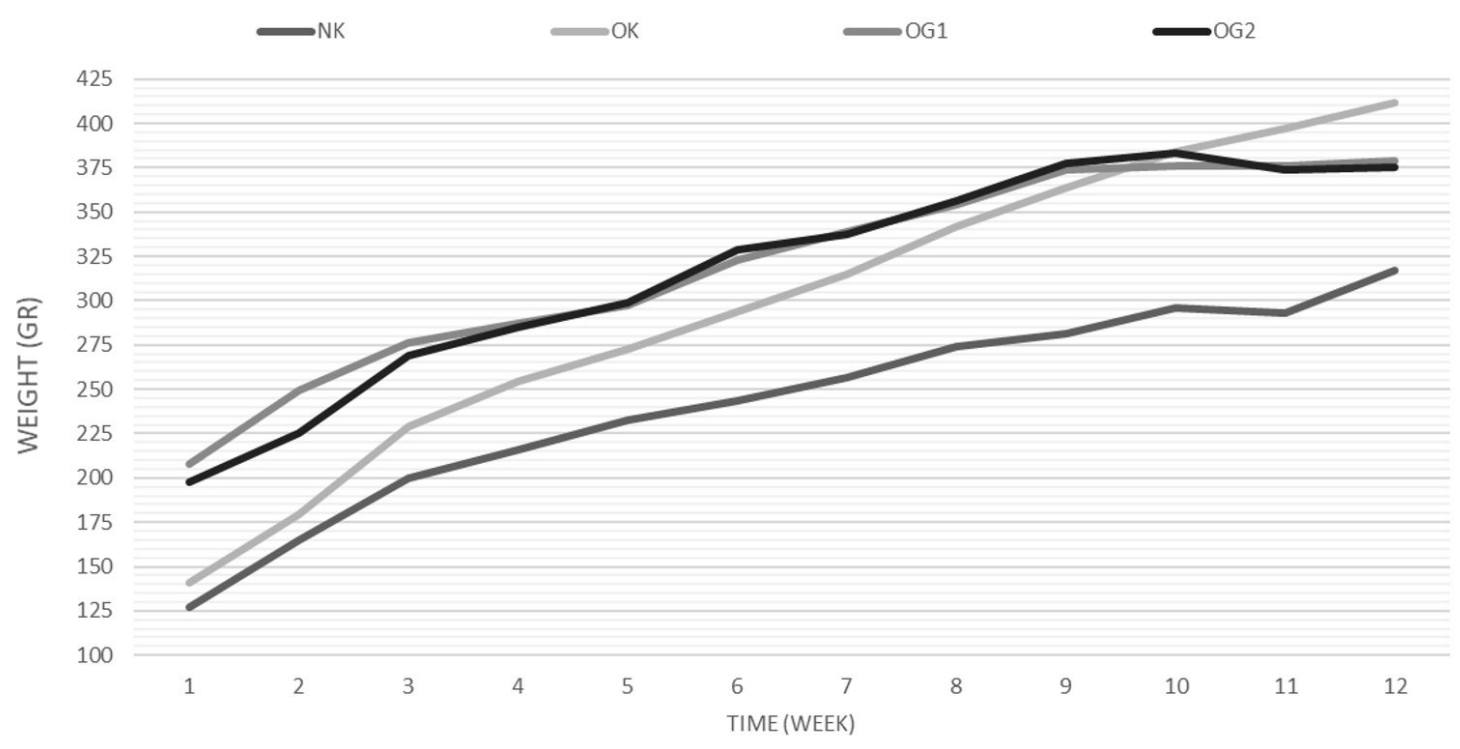

Figure 1. Time-linked variation in body weights in the experimental groups.

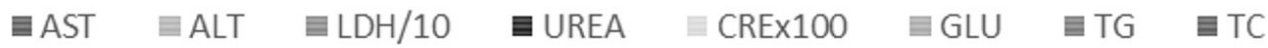

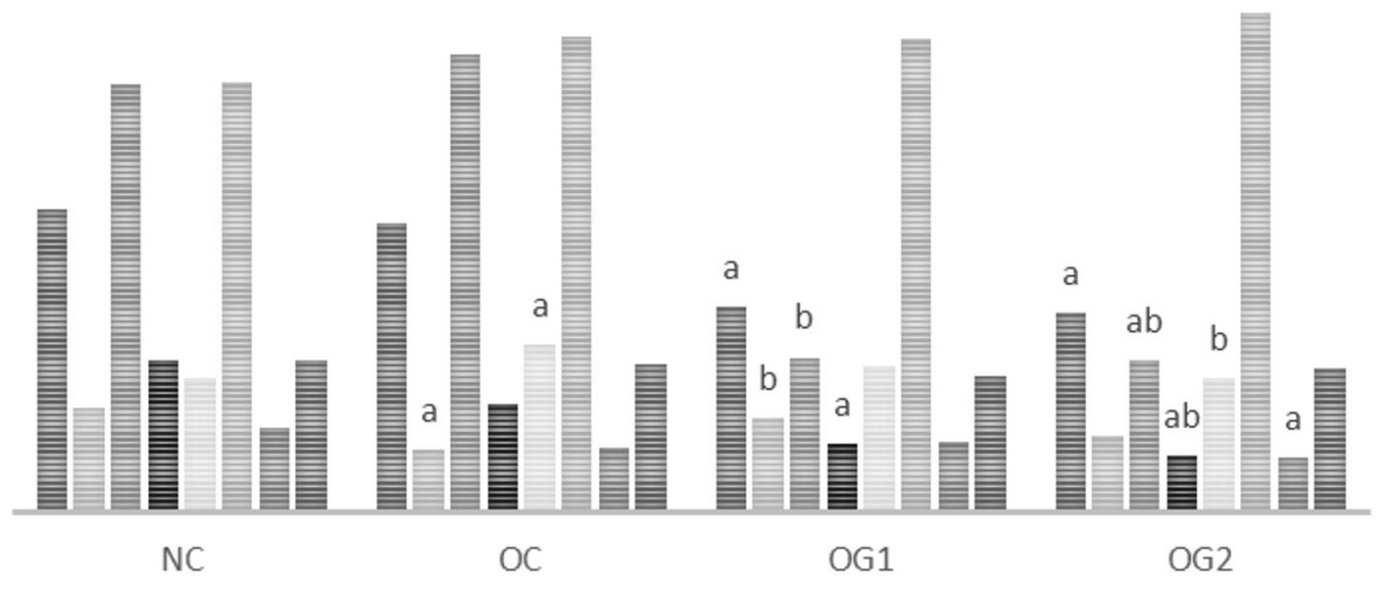

Figure 2. Serum levels in tissue in experimental groups. (a) Statistically significant difference compared to control group ( $\mathrm{p}<0.05$ ); (b) Statistically significant difference compared to the obese group $(\mathrm{p}<0.05)$.

caused falls in creatinine and urea levels. In parallel with the present study, there was a reduction in urea levels in the OG1 group as compared to the NC group and in the OG2 group compared to both the NC and OC groups at statistically significant levels. In terms of creatinine level, the OC group was increased compared to the NC group, while the OG2 group was reduced as compared to the OC group $(\mathrm{p}<0.05)$. In present study, the falls in creatinine and urea levels are evaluated due to the secondary metabolites in the plant used in the study (Figure 2).
The antioxidant defense levels in tissues are given in Table 1.

According to Table 1 SOD activity of lung and testis tissues in the OG2 group were observed to be significantly increased in a statistical sense compared to the OC group $(\mathrm{p}<0.05)$. In terms of CAT activity levels, lung tissue in the OG2 group had statistical increases compared to the OC group ( $p<0.05)$. In terms of GR activity levels, liver tissue in the OG1 and OG2 groups displayed statistically significant level of reduction as compared to the NC group; in brain 

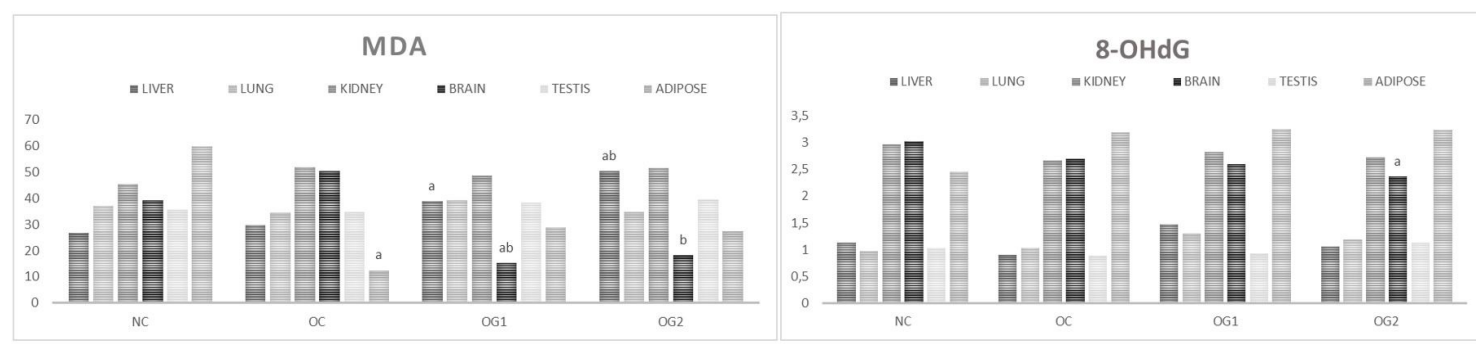

Figure 3. MDA and 8-OHdG (DNA damage) levels in tissues. (a) Statistically significant difference compared to control group ( $\mathrm{p}<0.05$ ); (b) Statistically significant difference compared to the obese group $(\mathrm{p}<0.05)$.

tissue the OG2 group displayed significant reduction in terms of statistics compared to both the NC and OC groups. Additionally, in terms of GPX activity levels, brain tissue in the OC group displayed a statistically significant reduction compared to the NC group, while additionally brain tissue in the OG1 group displayed an increase that was statistically significant as compared to the OC group $(\mathrm{p}<0.05)$. Again, in terms of GPX activity, lung tissue in the OG1 and OG2 groups had reduced levels compared to both NC and OC groups, while kidney tissue in the OG2 group had a statistically significant increase compared to both the NC and OC groups $(\mathrm{p}<0.05)$. Additionally, in testis tissue in the OG2 group, there was a reduction compared to both NC and OC groups, while in adipose tissue in the OG2 group there was a statistically significant fall observed as compared to the NC group $(\mathrm{p}<0.05)$. In terms of GST activity levels, liver tissue in the OC and OG1 groups reduced compared to the NC group, while in the OG2 group the increase compared to the OC group was found to be statistically significant $(\mathrm{p}<0.05)$. Additionally, in adipose tissue in the OG2 group there was a reduction observed that was statistically significant as compared to the OC group ( $\mathrm{p}<0.05$ ). Again, according to Table 1, GSH activity levels in kidney tissue in the OG1 group reduced compared to both the NC and OC groups, while in testis tissue in the OG1 group the reduction compared to the OC group was statistically significant $(\mathrm{p}<0.05)$.

Obesity generally lowers CAT, GR and GPX levels, stated to be among the causes of lowered antioxidant capacity (Carmiel-Haggai et al., 2005). Additionally, Husain et al. (2005) in studies stated that enzymatic antioxidants like SOD, CAT and GPX can stop the formation of, or scavenge, reactive oxygen species. In accordance with these studies, the results of our study show Gundelia tournefortii L. plant extract significantly increased SOD and CAT content in lung tissue. The reason for this increase is shown to be the compensatory adaptation of increasing SOD values against oxidative stress in obese subjects (Weidig et al., 2004; Ansari et al., 2012) Another study stated that antioxidant enzyme activities significantly reduced in the HFD control group and the cardiac antioxidant enzyme activities in the HFD+PTV (Pitavastatin), HFD+RSV (Rosuvastatin) and HFD+Orlistat groups increased significantly (Ansari et al., 2012). Additionally, in some studies, antioxidants are stated to act as regulators of obesity in rats and mice with HFD (Han et al., 2003; Ansari et al., 2012). The results of our study are similar to these previous studies, with significant falls observed in antioxidant activities in the HCD (high calorie diet) group especially, while significant increases were found in SOD activity in testis and lung tissue, in GPX activity in brain tissue, in GST activity in liver tissue and CAT activity in lung tissue in the groups administered plant extract. The present findings increase the possibility that Gundelia tournefortii L. plant can be administered as an antiobesity therapeutic method.

The effects on MDA (lipid peroxidation) and 8-OHdG (DNA damage) in tissues in the experimental groups are given in Figure 3. MDA is one of the products of peroxidation of unsaturated fat acids and is a marker of oxidative damage (Draper and Hadley, 1990; Nasri et al., 2015; Amri et al., 2017). When the MDA values in the study findings are investigated, there were increases observed in liver tissue in the OG1 and OG2 groups as compared to the control group and in the OG2 group compared to the obese group $(\mathrm{p}<0.05)$. As MDA is the final lipid peroxidation product in cell membranes and lipid peroxidation is one of the molecular mechanisms included in obesity-linked toxicity, this may be the reason for this increase (Meng et al., 2011; Emami et al., 2016). Additionally, MDA levels in brain tissue reduced in the OG1 and OG2 groups compared to the obese group and significantly reduced in the OG1 group compared to the control group $(p<0.05)$. The formation of this situation is evaluated as the result of secondary components included in Gundelia tournefortii L. plant extract having positive effects on lipid peroxidation. Additionally, when MDA levels are examined in terms of adipose tissue, the OC group was observed to have significantly reduced levels compared to the NC group ( $\mathrm{p}<0.05)$. In parallel with our results, the study by Kahraman et al. (2018) stated that brown adipose tissue in rats fed with high-fat diet had higher carbonic anhydrase III mRNA expression in the obese group as compared to the control group, while MDA level was lower and they concluded that oxidative stress was partly suppressed. Additionally, another study by Galinier et al. (2006) with obese and Zucker rats showed that brown adipose tissue had certain redox state and could protect itself against oxidative stress during obesity with a variety of enzymatic and nonenzymatic antioxidant molecule levels.

8-OHdG (8-hydroxy-2-deoxyguanosine) is known as a marker of oxidative DNA damage (Huh et al., 2017). HFD consumption is stated to increase the speed of oxidative stress and oxidative DNA damage (Gandhi and 
Table 1. Antioxidant defense levels in tissues.

\begin{tabular}{|c|c|c|c|c|c|}
\hline \multirow{2}{*}{ TISSUES } & \multirow{2}{*}{ PARAMETERS } & \multicolumn{4}{|c|}{ GROUPS } \\
\hline & & NC $\bar{X} \pm S D$ & OC $\bar{X} \pm S D$ & OG1 $\bar{X} \pm S D$ & OG2 $\bar{X} \pm S D$ \\
\hline \multirow[t]{6}{*}{ LIVER } & SOD & $1449.04 \pm 465.14$ & $1089.61 \pm 424.53$ & $1260.5 \pm 162.37$ & $1332.79 \pm 397.44$ \\
\hline & CAT & $185.19 \pm 24.09$ & $199.34 \pm 29.38$ & $179.70 \pm 23.69$ & $171.79 \pm 80.39$ \\
\hline & GR & $1.49 \pm 0.35$ & $0.77 \pm 0.10$ & $0.62 \pm 0.16^{a}$ & $0.63 \pm 0.24^{\mathrm{a}}$ \\
\hline & GPX & $24.22 \pm 3.24$ & $25.12 \pm 2.82$ & $27.35 \pm 2.96$ & $23.65 \pm 3.54$ \\
\hline & GST & $4.25 \pm 0.63$ & $2.73 \pm 1.14^{\mathrm{a}}$ & $3.30 \pm 0.95^{\mathrm{a}}$ & $4.19 \pm 0.17^{b}$ \\
\hline & GSH & $24.68 \pm 1.47$ & $22.83 \pm 3.52$ & $20.44 \pm 1.75$ & $25.98 \pm 2.18$ \\
\hline \multirow[t]{6}{*}{ LUNG } & SOD & $1650.25 \pm 96.97$ & $1334.71 \pm 251.82$ & $1642.11 \pm 353.68$ & $1480.78 \pm 231.88^{b}$ \\
\hline & CAT & $20.47 \pm 3.85$ & $18.05 \pm 4.88$ & $23.73 \pm 6.2$ & $30.05 \pm 5.46^{\mathrm{b}}$ \\
\hline & GR & $0.99 \pm 0.14$ & $0.46 \pm 0.73$ & $0.93 \pm 0.22$ & $0.87 \pm 0.16$ \\
\hline & GPX & $16.63 \pm 2.79$ & $16.14 \pm 1.35$ & $11.27 \pm 1.98^{\mathrm{ab}}$ & $12.33 \pm 1.33^{\mathrm{ab}}$ \\
\hline & GST & $0.52 \pm 0.14$ & $0.32 \pm 0.03$ & $0.36 \pm 0.14$ & $0.50 \pm 0.17$ \\
\hline & GSH & $17.85 \pm 2.43$ & $18.31 \pm 2.13$ & $14.10 \pm 3.41$ & $13.18 \pm 2.58$ \\
\hline \multirow[t]{6}{*}{ KIDNEY } & SOD & $2022.24 \pm 99.46$ & $2041.76 \pm 36.66$ & $2137.69 \pm 76.23$ & $2045.98 \pm 133.9$ \\
\hline & CAT & $118.09 \pm 29.54$ & $115.95 \pm 27.27$ & $137.54 \pm 37.75$ & $123.30 \pm 32.72$ \\
\hline & GR & $0.73 \pm 0.30$ & $0.89 \pm 0.21$ & $0.97 \pm 0.12$ & $0.85 \pm 0.05$ \\
\hline & GPX & $25.07 \pm 3.6$ & $27.23 \pm 3.02$ & $30.55 \pm 4.24$ & $35.56 \pm 2.30^{\mathrm{ab}}$ \\
\hline & GST & $0.58 \pm 0.18$ & $0.55 \pm 0.11$ & $0.61 \pm 0.29$ & $0.63 \pm 0.24$ \\
\hline & GSH & $17.99 \pm 2.97$ & $18.73 \pm 1.74$ & $9.06 \pm 1.24^{\mathrm{ab}}$ & $16.69 \pm 3.04$ \\
\hline \multirow[t]{6}{*}{ BRAIN } & SOD & $2011.50 \pm 78.5$ & $1969.58 \pm 115.45$ & $1992.28 \pm 46.03$ & $2106.02 \pm 22.2$ \\
\hline & CAT & $3.9 \pm 1.57$ & $3.72 \pm 2.04$ & $4.37 \pm 1.88$ & $4.65 \pm 1.3$ \\
\hline & GR & $0.34 \pm 0.03$ & $0.35 \pm 0.06$ & $0.26 \pm 0.04$ & $0.25 \pm 0.02^{\mathrm{ab}}$ \\
\hline & GPX & $25.92 \pm 1.02$ & $19.83 \pm 1.93^{\mathrm{a}}$ & $24.52 \pm 1.84^{\mathrm{b}}$ & $22.57 \pm 1.45$ \\
\hline & GST & $0.52 \pm 0.09$ & $0.68 \pm 0.11$ & $0.56 \pm 0.12$ & $0.48 \pm 0.2$ \\
\hline & GSH & $8.25 \pm 1.08$ & $8.07 \pm 0.35$ & $7.73 \pm 1.08$ & $7.03 \pm 0.95$ \\
\hline \multirow[t]{6}{*}{ TESTIS } & SOD & $1624.86 \pm 284.41$ & $1466.10 \pm 285.07$ & $1672.63 \pm 225.63$ & $1887.66 \pm 137.59^{b}$ \\
\hline & CAT & $9.49 \pm 4.22$ & $10.51 \pm 2.43$ & $10.79 \pm 4.39$ & $12.65 \pm 8.12$ \\
\hline & GR & $0.11 \pm 0.03$ & $0.10 \pm 0.01$ & $0.10 \pm 0.01$ & $0.10 \pm 0.03$ \\
\hline & GPX & $38.61 \pm 0.84$ & $38.48 \pm 0.88$ & $35.65 \pm 2.57$ & $30.80 \pm 1.36^{\mathrm{ab}}$ \\
\hline & GST & $3.90 \pm 0.48$ & $4.18 \pm 1.12$ & $3.41 \pm 0.87$ & $3.05 \pm 0.51$ \\
\hline & GSH & $7.32 \pm 0.57$ & $8.12 \pm 0.75$ & $6.21 \pm 0.71^{\mathrm{b}}$ & $7.34 \pm 1.25$ \\
\hline \multirow[t]{6}{*}{ ADIPOSE } & SOD & $1466.83 \pm 298.31$ & $1871.14 \pm 109.41$ & $1914.34 \pm 179.62$ & $1669.59 \pm 387.49$ \\
\hline & CAT & $2.79 \pm 0.35$ & $2.14 \pm 1.24$ & $2.41 \pm 0.45$ & $2.23 \pm 0.60$ \\
\hline & GR & $3.64 \pm 0.56$ & $3.57 \pm 0.35$ & $3.45 \pm 0.33$ & $3.63 \pm 0.13$ \\
\hline & GPX & $26.9 \pm 1.95$ & $26.17 \pm 2.38$ & $24.75 \pm 3.41$ & $23.83 \pm 1.36^{\mathrm{a}}$ \\
\hline & GST & $0.04 \pm 0.40$ & $0.04 \pm 0.01$ & $0.03 \pm 0.01$ & $0.03 \pm 0.004^{\mathrm{b}}$ \\
\hline & GSH & $0.53 \pm 0.13$ & $0.36 \pm 0.07$ & $0.51 \pm 0.20$ & $0.38 \pm 0.28$ \\
\hline
\end{tabular}

$\overline{\mathrm{X}}=$ Mean; $\mathrm{SD}=$ Standard derivation. a: Statistically significant difference compared to control group ( $<<0.05)$. b: Statistically significant difference compared to the obese group $(\mathrm{p}<0.05)$.

Kaur, 2012). Additionally, Włodarczyk and Nowicka (2019) stated that oxidative stress and inflammation induced by obesity caused DNA damage in different tissues. When the findings obtained in the study are examined (Figure 3), for brain tissue the significant fall in the OG2 group compared to the control group is evaluated as due to regulation of negative changes occurring due to DNA damage with HCD by the additionally administered plant extract. Similarly, 
in a study conducted on the Rheum ribes L. plant, it was reported that the 8-OHdG level in the plant dose groups was lower than the control group (Bati et al., 2020). In present study, the groups administered plant extract had lower DNA damage level compared to the control group and this situation is thought to be due to the plant extract.

Considering all these results, our study complies with the literature. In terms of antioxidant activities, HCD consumption causes reductions in antioxidant parameter values in different tissues; however, in groups administered plant extract there were significant increases in antioxidant parameter values compared to the group consuming HCD. Studies determined that Gundelia tournefortii L. has high total phenolic content and antioxidant capacity (Coruh et al., 2007; Konak et al., 2017). Gundelia tournefortii L. used in the study and consumed abundantly in our country appeared to display positive effects on antioxidant parameter values and is considered to be an antioxidant source that may be used in daily diets.

\section{Conclusion}

In conclusion, oxidative changes in tissue are said to be related to metabolic irregularities in obesity and develop linked to it. The present findings show that oxidative stress and antioxidant enzyme profiles are variable in different tissues, administration of Gundelia tournefortii L. plant extract increases antioxidant enzyme activities in tissues, especially lung tissue and has a significant effect in terms of the oxidant-antioxidant balance.

\section{Acknowledgements}

This work was supported by the Van Yüzüncü Yıl University Scientific Research Projects Coordination Unit under Grant [TSA-2017-5473].

\section{References}

ALTUNKAYNAK, M.E., OZBEK, E., ALTUNKAYNAK, B.Z., CAN, I., UNAL, D. and UNAL, B., 2008. The effects of high-fat diet on the renal structure and morphometric parametric of kidneys in rats. Journal of Anatomy, vol. 212, no. 6, pp. 845-852. http:// dx.doi.org/10.1111/j.1469-7580.2008.00902.x. PMid:18510511.

AMRI, Z., GHORBEL, A., TURKI, M., AKROUT, F.M., AYADI, F., ELFEKI, A. and HAMMAMI, M., 2017. Effect of pomegranate extracts on brain antioxidant markers and cholinesterase activity in high fat-high fructose diet induced obesity in rat model. BMC Complementary and Alternative Medicine, vol. 17, no. 1, pp. 339. http://dx.doi.org/10.1186/s12906-017-1842-9. PMid:28655305.

ANSARI, J.A., BHANDARI, U., HAQUE, S.E. and PILLAI, K.K., 2012. Enhancement of antioxidant defense mechanism by pitavastatin and rosuvastatin on obesity-induced oxidative stress in Wistar rats. Toxicology Mechanisms and Methods, vol. 22, no. 1, pp. 67-73. http://dx.doi.org/10.3109/15376516.2011.60339 1. PMid:21859367.

ARAO, K., YOTSUMOTO, H., HAN, S.Y., NAGAO, K. and YANAGITA, T., 2004. The 9cis,11trans,13cis isomer of conjugated linolenic acid reduces apolipoprotein B100 secretion and triacylglycerol synthesis in HepG2 cells. Bioscience, Biotechnology, and
Biochemistry, vol. 68, no. 12, pp. 2643-2645. http://dx.doi. org/10.1271/bbb.68.2643. PMid:15618643.

ASADI-SAMA, M., RAFIEIAN-K, M. and AZIMI, N., 2013. Gundelia a systematic review of medicinal and molecular perspective. Pakistan Journal of Biological Sciences, vol. 16, no. 21, pp. 1238-1247. http://dx.doi.org/10.3923/pjbs.2013.1238.1247. PMid:24511731.

BATI, B., CELIK, I., ERAY, N., TURAN, A. and ALKAN, E.E., 2019. The efects of Gundelia tournefortii L. plant extract on hematological parameters in rats fed high fat diet. Beykent Univercity J Sci Enginer, vol. 11, no. 2, pp. 34-41.

BATI, B., CELIK, I., TURAN, A., ERAY, N., ALKAN, E.E. and ZIREK, A.K., 2020. Effect of isgin (Rheum ribes L.) on biochemical parameters, antioxidant activity and DNA damage in rats with obesity induced with high-calorie diet. Archives of Physiology and Biochemistry, pp. 1-9. http://dx.doi.org/10.1080/1381345 5.2020.1819338. PMid:32924615.

BERK, M., NG, F., DEAN, O., DODD, S. and BUSH, A.I., 2008. Glutathione: a novel treatment target in psychiatry. Trends in Pharmacological Sciences, vol. 29, no. 7, pp. 346-351. http:// dx.doi.org/10.1016/j.tips.2008.05.001. PMid:18538422.

CAKMAK, K.C. and GULCIN, I., 2019. Anticholinergic and antioxidant activities of usnic acid-an activity-structure insight. Toxicology Reports, vol. 6, pp. 1273-1280. http://dx.doi.org/10.1016/j. toxrep.2019.11.003. PMid:31832335.

CARMIEL-HAGGAI, M., CEDERBAUM, A.I. and NIETO, N., 2005. A high-fat diet leads to the progression of non-alcoholic fatty liver disease in obese rats. The FASEB Journal, vol. 19, no. 1, pp. 136138. http://dx.doi.org/10.1096/fj.04-2291fje. PMid:15522905.

CORUH, N., SAG ``IÇOG ${ }^{`}$ LU CELEP, A.G., OZGOKCE, F. and ISCAN, M., 2007. Antioxidant capacities of Gundelia tournefortii L. extracts and inhibition on glutathione-S-transferase activity. Food Chemistry, vol. 100, no. 3, pp. 1249-1253. http://dx.doi. org/10.1016/j.foodchem.2005.12.008.

DALAR, A. and KONCZAK, I., 2013. Phenolic contents, antioxidant capacities and inhibitory activities against key metabolic syndrome relevant enzymes of herbal teas from Eastern Anatolia. Industrial Crops and Products, vol. 44, pp. 383-390. http://dx.doi.org/10.1016/j.indcrop.2012.11.037.

DRAPER, H.H. and HADLEY, M., 1990. Malondialdehyde determination as index of lipid peroxidation. Methods in Enzymology, vol. 186, pp. 421-431. http://dx.doi.org/10.1016/0076-6879(90)86135-I. PMid:2233309.

EMAMI, S.R., JAFARI, M., HAGHSHENAS, R. and RAVASI, A., 2016. Impact of eight weeks endurance training on biochemical parameters and obesity-induced oxidative stress in high fat diet-fed rats. Journal of Exercise Nutrition E Biochemistry, vol. 20, no. 1, pp. 29-35. http://dx.doi.org/10.20463/jenb.2016.03.20.1.5. PMid:27298810.

ERDURMUŞ, M., YAGCI, R., ATIS, O., KARADAG, R., AKBAS, A. and HEPSEN, I.F., 2011. Antioxidant status and oxidative stress in primary open angle glaucoma and pseudoexfoliative glaucoma. Current Eye Research, vol. 36, no. 8, pp. 713-718. http://dx.doi. org/10.3109/02713683.2011.584370. PMid:21780920.

GALINIER, A., CARRIERE, A., FERNANDEZ, Y., CASPAR-BAUGUIL, S., PERIQUET, B., PERIQUET, A., PENICAUD, L. and CASTEILLA, L., 2006. Site specific changes of redox metabolism in adipose tissue of obese Zucker rats. FEBS Letters, vol. 580, no. 27, pp. 6391-6398. http://dx.doi.org/10.1016/j.febslet.2006.10.052. PMid:17098232.

GANDHI, G. and KAUR, G., 2012. Assessment of DNA damage in obese individuals. Res J Biol, vol. 2, no. 2, pp. 37-44. 
GULCIN, I., 2020. Antioxidants and antioxidant methods: an updated overview. Archives of Toxicology, vol. 94, no. 3, pp. 651-715. http:// dx.doi.org/10.1007/s00204-020-02689-3. PMid:32180036.

GUTTERIDGE, J.M.C., 1994. Biological origin of free radicals, and mechanisms of antioxidant protection. Chemico-Biological Interactions, vol. 91, no. 2-3, pp. 133-140. http://dx.doi. org/10.1016/0009-2797(94)90033-7. PMid:8194129.

HALIMA, B.H., SONIA, G., SARRA, K., HOUDA, B.J., FETHI, B.S. and ABDALLAH, A., 2018. Apple cider vinegar attenuates oxidative stress and reduces the risk of obesity in high-fat-fed male wistar rats. Journal of Medicinal Food, vol. 21, no. 1, pp. 70-80. http:// dx.doi.org/10.1089/jmf.2017.0039. PMid:29091513.

HAN, L.K., SUMIYOSHI, M., ZHANG, J., LIU, M.X., ZHANG, X.F., ZHENG, Y.N., OKUDA, H. and KIMURA, Y., 2003. Anti-obesity action of Salix matsudana leaves (Part 1). Anti-obesity action by polyphenols of Salix matsudana in high fat-diet treated rodent animals. Phytotherapy Research, vol. 17, no. 10, pp. 1188-1194. http://dx.doi.org/10.1002/ptr.1404. PMid:14669254.

HERNÁNDEZ-GUERRERO, C., PARRA-CARRIEDO, A., RUIZ-DESANTIAGO, D., GALICIA-CASTILLO, O., BUENROSTRO-JÁUREGUI M., and DÍAZ-GUTIÉRREZ, C., 2018. Genetic polymorphisms of antioxidant enzymes CAT and SOD affect the outcome of clinical, biochemical, and anthropometric variables in people with obesity under a dietary intervention. Genes $\mathcal{E}$ Nutrition, vol. 13, pp. 1.

HUH, J.Y., JUNG, I., PIAO, L., HA, H. and CHUNG, M.H., 2017. 8-Hydroxy2-deoxyguanosine ameliorates high-fat diet-induced insulin resistance and adipocyte dysfunction in mice. Biochemical and Biophysical Research Communications, vol. 491, no. 4, pp. 890-896. http://dx.doi.org/10.1016/j.bbrc.2017.07.132. PMid:28754587.

HUSAIN, K., MEJIA, J., LALLA, J. and KAZIM, S., 2005. Dose response of alcoholinduced changes in BP, nitric oxide and antioxidants in rat plasma. Pharmacological Research, vol. 51, no. 4, pp. 337-343. http://dx.doi.org/10.1016/j.phrs.2004.10.005. PMid:15683747.

ISLAM, M.T., ALI, E.S. and MUBARAK, M.S., 2020. Anti-obesity effect of plant diterpenes and their derivatives: a review. Phytotherapy Research, vol. 34, no. 6, pp. 1216-1225. http://dx.doi.org/10.1002/ ptr.6602. PMid:31977122.

KAHRAMAN, C., ALVER, A., SENTURK, A. and AKCA, I.I., 2018. The relationship between carbonic anhydrase-III expression and oxidative stress in brown adipose tissue. Dicle Medical Journal, vol. 45, no. 4, pp. 361-368. http://dx.doi.org/10.5798/ dicletip.497874.

KARAASLAN, O., COTELI, E. and KARATAS, F., 2014. Investigation of amounts of $\mathrm{A}, \mathrm{E}, \mathrm{C}$ vitamins with malondialdehyde and glutathıone in plant Gundelı Tournefortıl. Erzincan Univercity J Sci and Technology, vol. 7, no. 2, pp. 159-168.

KIM, J.Y., NOLTE, L.A., HANSEN, P.A., HAN, D.H., FERGUSON, K., THOMPSON, P.A. and HOLLOSZY, J.O., 2000. High-fat dietinduced muscle insulin resistance: relationship to visceral fat mass. American Journal of Physiology. Regulatory, Integrative and Comparative Physiology, vol. 279, no. 6, pp. R2057-2065. http:// dx.doi.org/10.1152/ajpregu.2000.279.6.R2057. PMid:11080069.

KONAK, M., ATES, M. and SAHAN, Y., 2017. Evaluation of antioxidant properties of Gundelia tournefortii: a wild edible plant. J Agn Faculty of Bursa Uludağ University, vol. 31, no. 2, pp. 101-108.

LI, M., YE, T., WANG, X., LI, X., QIANG, O., YU, T., TANG, C. and LIU, R., 2016. Effect of octreotide on hepatic steatosis in diet-induced obesity in rats. PLoS One, vol. 11, no. 3, pp. e0152085. http:// dx.doi.org/10.1371/journal.pone.0152085. PMid:27002331.

MACEDO, I., MEDEIROS, L., OLIVEIRA, C., OLIVEIRA, C., ROZISKY, J., SCARABELOT, V., SOUZA, A., SILVA, F.R., SANTOS, V.S., CIOATO, S.G., CAUMO, W. and TORRES, I.L.S., 2012. Cafeteria diet- induced obesity plus chronic stress alter serum leptin levels. Peptides, vol. 38, no. 1, pp. 189-196. http://dx.doi.org/10.1016/j. peptides.2012.08.007. PMid:22940203.

MATSUSHITA, K., YASUDA, G., SHOUDA, M. and UMEMURA, S., 2009. Evaluation of renal function and proteinuria based on mass health examinations in young Japanese obese adults. Clinical and Experimental Nephrology, vol. 13, pp. 316-324. http://dx.doi.org/10.1007/s10157-009-0164-8. PMid:19377907.

MENG, R., ZHU, D.L., BI, Y., YANG, D.H. and WANG, Y.P., 2011. Antioxidative effect of apocynin on insulin resistance in high-fat diet mice. Annals of Clinical and Laboratory Science, vol. 41, no. 3, pp. 236-243. PMid:22075506.

MERCANLIGIL, S.M. 2012. Obesity. Report No: 729. Ankara, Turkey: Public Health Agency of Turkey Ministry of Health.

MERYEM, B., SAMIRA, B., ZOHRA, B., HAFIDA, M., MERZOUK, S., and MICHEL, N., 2016. Effects of cafeteria diet on lipid metabolism and lipase activities in Wistar rats. European Chemical Bulletin, vol. 5, no. 3, pp. 99-103.

MUMCU, U.Y., KOCER, I., ATES, O. and ALP, H.H., 2016. Decreased paraoxonase 1 activity and increased malondialdehyde and oxidative DNA damage levels in primary open angle glaucoma. International Journal of Ophthalmology, vol. 9, no. 10, pp. 15181520. PMid:27803873.

NASRI, R., ABDELHEDI, O., JEMIL, I., DAOUED, I., HAMDEN, K., KALLEL, C., ELFEKI, A., LAMRI-SENHADJI, M., BOUALGA, A., NASRI, M. and KARRA-CHÂABOUNI, M., 2015. Ameliorating effects of goby fish protein hydrolysates on high-fat-highfructose dietinduced hyperglycemia, oxidative stress and deterioration of kidney function in rats. Chemico-Biological Interactions, vol. 242, pp. 71-80. http://dx.doi.org/10.1016/j.cbi.2015.08.003. PMid:26327248.

NIU, S., WANG, L., HE, M., PENG, Y. and LI, S., 2015. Exendin-4 regulates redox homeostasis in rats fed with high-fat diet. Acta Biochimica et Biophysica Sinica, vol. 47, no. 6, pp. 397-403. http:// dx.doi.org/10.1093/abbs/gmv027. PMid:25910576.

POLAT, R., CAKILCIOGLU, U., ERTUG, F. and SATIL, F., 2012. An evaluation of ethnobotanical studies in Eastern Anatolia. Biodiversity and Conservation, vol. 5, no. 2, pp. 23-40.

PUNHAGUI, A.P.F., TEIXEIRA, G.R., DE FREITAS, M.C., SERAPHIM, P.M. and FERNANDES, G.S.A., 2018. Intermittent resistance exercise and obesity, considered separately or combined, impair spermatic parameters in adult male Wistar rats. International Journal of Experimental Pathology, vol. 99, no. 2, pp. 95-102. http://dx.doi.org/10.1111/iep.12270. PMid:29781539.

QNAIS, E., BSEISO, Y., WEDYAN, M., AL-OMARI, M. and ALKHATEEB, H., 2016. Chemical composition and antinociceptive effects of essential oil from aerial parts of Gundelia tournefortii L Asteraceae (Compositae) in rats. Tropical Journal of Pharmaceutical Research, vol. 15, no. 10, pp. 2183-2190. http:// dx.doi.org/10.4314/tjpr.v15i10.17.

R DEVELOPMENT CORE TEAM, 2020. R: A language and environment for statistical computing [software]. Vienna: R Foundation for Statistical Computing.

SAYIN, F.K., BUYUKBAS, S., BASARALI, M.K., ALP, H., TOY, H. and UGURCU, V., 2016. Effects of Silybum marianum extract on high-fat diet induced metabolic disorders in rats. Polish Journal of Food and Nutrition Sciences, vol. 66, no. 1, pp. 43-49. http:// dx.doi.org/10.1515/pjfns-2015-0014.

TURAN, A. and CELIK, I., 2016. Antioxidant and hepatoprotective properties of dried fig against oxidative stress and hepatotoxicity in rats. International Journal of Biological Macromolecules, vol. 91, pp. 554-559. http://dx.doi.org/10.1016/j.ijbiomac.2016.06.009. PMid:27268385. 
TURKEY HEALTHY EATING AND ACTIVE LIFE PROGRAM - THSK 2013. Report No: 773. Ankara, Turkey: Public Health Agency of Turkey Ministry of Health.

VALKO, M., LEIBFRITZ, D., MONCOL, J., CRONIN, M.T.D., MAZUR, M. and TELSER, J., 2007. Free radicals and antioxidants in normal physiological functions and human disease. The International Journal of Biochemistry \& Cell Biology, vol. 39, no. 1, pp. 44-84. http://dx.doi.org/10.1016/j.biocel.2006.07.001. PMid:16978905.

WEIDIG, P., MCMASTER, D. and BAYRAKTUTAN, U., 2004. High glucose mediates pro-oxidant and antioxidant enzyme activities in coronary endothelial cells. Diabetes, Obesity \& Metabolism, vol. 6, no. 6, pp. 432-441. http://dx.doi.org/10.1111/j.14628902.2004.00364.x. PMid:15479219.

WILDBURGER, R., MRAKOVCIC, L., STROSER, M., ANDRISIC, L., BOROVIC SUNJIC, S., ZARKOVIC, K. and ZARKOVIC, N., 2009. Lipid peroxidation and age-associated diseases-cause or consequence: review citation. Turkiye Klinikleri J Med Sci, vol. 29, no. 1, pp. 189-193.

WŁODARCZYK, M. and NOWICKA, G., 2019. Obesity, DNA damage, and development of obesity-related diseases. International Journal of Molecular Sciences, vol. 20, no. 5, pp. 1146. http:// dx.doi.org/10.3390/ijms20051146. PMid:30845725.
WORLD HEALTH ORGANIZATION - WHO 2020 [viewed 4 April 2020]. Controlling the global obesity epidemic, the challange [Internet]. WHO. Available from: http://www.who.int/nutrition/ topics/obesity/en/.

YOU, J.S., LEE, Y.J., KIM, K.S., KIM, S.H. and CHANG, K.J., 2014. Ethanol extract of lotus (Nelumbo nucifera) root exhibits an anti-adipogenic effect in human pre-adipocytes and anti-obesity and anti-oxidant effects in rats fed a high-fat diet. Nutrition Research, vol. 34, no. 3, pp. 258-267. http://dx.doi.org/10.1016/j. nutres.2014.01.003. PMid:24655493.

YUKI, K. and TSUBOTA, K., 2013. Increased urinary 8-hydroxy2'-deoxyguanosine (8-OHdG)/creatinine level is associated with the progression of normal-tension glaucoma. Current Eye Research, vol. 38, no. 9, pp. 983-988. http://dx.doi.org/10. 3109/02713683.2013.800889. PMid:23767426.

ZADÁK, Z., HYSPLER, R., TICHÁ, A., HRONEK, M., FIKROVÁ, P., RATHOUSKÁ, J., HRNCIARIKOVÁ, D. and STETINA, R., 2009. Antioxidants and vitamins in clinical conditions. Physiological Research, vol. 58, no. 1, suppl. 1, pp. S13-17. http://dx.doi. org/10.33549/physiolres.931861. PMid:19857031. 